\title{
Relation between job mobility during working life and health state after retirement: a cross sectional study of 627 subjects living in the Paris area
}

\author{
Yuriko Iwatsubo, Francis Derriennic, Bernard Cassou
}

\begin{abstract}
The relation between job mobility during working life and health state after retirement was studied in a random sample of 627 retired men and women living in the Paris area who were beneficiaries of an interprofessional supplementary pension fund. State of health was evaluated by the number of health impairments that these subjects reported at the time of interview. Job mobility was defined by a dichotomic variable based on the number of different companies and branches of economic activity in which the subjects had worked. This information was obtained from the individual records supplied by the pension fund. For both sexes, a significant relation was found between the number of health impairments and job mobility: for men, the mean number of impairments was 1.7 in the high mobility group and 1.3 in the low mobility group, and for women these numbers were respectively $2 \cdot 1$ and $1 \cdot 7$. This finding seemed independent of the effects of selection and of the effects of factors such as age at the time of interview, age at retirement, previous diseases, past work accidents, and previous occupational exposures. These results suggest that a high job mobility during working life might be a risk factor for health after retirement.
\end{abstract}

Job mobility is a complex problem which concerns a large fraction of the working population. In France, a survey by the Institut National de la Statistique et des Etudes Economiques (INSEE) has shown that between 1980 and $198520 \%$ of the working population changed the company for which they worked, $8 \%$ both their company and branch of economic activity, and $13 \%$ their socioeconomic category. ${ }^{1}$

\begin{tabular}{l}
\hline INSERM U170-16 Avenue Paul Vaillant- \\
Couturier_94807 Villejuif Cedex \\
Y Iwatsubo, F Derriennic \\
Centre de Gérontologie_Hôpital Sainte-Périne-49 \\
Rue Mirabeau-75016 Paris \\
B Cassou
\end{tabular}

In most epidemiological studies of occupational exposure and working conditions in relation to health, the problem of job mobility is essentially discussed in terms of possible bias in measuring the relation between occupational factors and disease or, more generally, conditions of health. ${ }^{2}$ The main process referred to is the "healthy worker effect," which includes the processes of selection or self selection by working populations as a function of health. Today, it is generally recognised that not only entering employment, ${ }^{3}$ but also staying in the same occupation, are partly conditioned by health criteria. $^{45}$

Although a sufficiently good state of health seems necessary to remain in active employment, little is yet known about the potential effects of frequent job changes on the evolution of health. Not many studies exist on the subject, but in two investigations ${ }^{67}$ concerning relatively young subjects (over 35 years old and 45 to 64 years old respectively), a link was reported between job mobility and the occurrence of coronary heart disease. On the whole, there is reason to believe that subjects must be followed up for long periods of their working life to enable those with high job mobility to be distinguished from the others, and that a sufficiently long period must elapse for the potential effects of such mobility on health to become statistically detectable.

Consequently, as Collins and Redmond suggested, ${ }^{8}$ retired subjects appear to constitute an interesting population for the study of this type of problem. That is why, on the basis of a longitudinal survey of the health of a group of retired men and women, ${ }^{9}$ we attempted to establish whether or not any connection exists between the degree of job mobility measured throughout working life and the state of health after retirement.

\section{Population and methods}

\section{SAMPLE AND DATA COLLECTION}

The present study was based on cross sectional data collected during the first stage of a longitudinal survey about the health of elderly people. The population studied comprised men and women living in the Paris area who were beneficiaries of an interprofessional supplementary pension fund. Many 
firms belonging to the private sector of industry are affiliated to this fund, which covers several branches of economic activity concerning chiefly the processing of metals, business, and transport. A sample of 993 subjects comprisng 484 retired men and 509 retired women was randomly selected in 1982 from the files provided by the pension fund concerned (Institut de Prévoyance Sociale Interentreprise; IPSIE). Of this total, 320 men and 307 women actually participated in the study, so that the participation rate was $63.1 \%$. The survey was carried out during the years 1982 and 1983 by home interviews based on a standardised questionnaire that was completed by investigators especially trained to interview elderly people.

For the present study, two sources of data were used: data relating to health supplied by subjects' answers at the time of these home interviews and data relating to job mobility obtained by compiling files that retraced the subjects' occupational history as recorded by the pension fund at the time of retirement.

\section{HEALTH PARAMETERS}

The questonnaire explored several areas concerned with health including previously diagnosed diseases, surgical operations, past work accidents, state of health on the day of the survey and current health care, and included closed ended questions about symptoms assumed to be easily identifiable by each subject. By grouping together the symptoms systematically investigated in the questionnaire, disorders of five major functions were defined as health impairments. ${ }^{10}$ Four of them concerned organic disorders. These were musculoskeletal impairment -that is, the presence of pains in joints or the spine for at least six months before the date of interview ( $51.6 \%$ of the men and $71.3 \%$ of the women)cardiorespiratory impairment defined as coughing or expectoration for three consecutive months during a period going back at least two years, or breathlessness or palpitation disturbing to daily activities (men $36.3 \%$, women $38.8 \%$ ), sight or hearing impairment comprising difficulties of sight or hearing in daily activities, even with corrective lenses or a hearing aid
(38.8\% for both sexes), and gastrointestinal impairment-that is, daily pains in the stomach or abdomen or constipation alternating with diarrhea (men $6.9 \%$, women $15 \%$ ). The fifth type of impairment concerned mental health, which was considered to be affected when at least five positive answers were given to nine questions taken from those used in Langner's scale of mental assessment ${ }^{11}$ (men $5.9 \%$, women, $15 \cdot 3 \%$ ). In our study, the state of health was evaluated in a quantitative manner by the number of impairments from which subjects were suffering at the time of the survey. This number was assumed to reflect the accumulation of health disorders that characterises the health of the elderly. ${ }^{12}$

\section{JOB MOBILITY}

At the time of retirement, the pension fund retraces each member's occupational history by compiling a list of companies for which they have worked. This is important, as the calculation of a portion of the retirement pension depends on it. The procedure used is the same for all subjects who must prove to the pension fund that at the time of their retirement they had indeed worked for the companies they cite. In most cases the branch of activity in which the companies concerned are engaged is known because of the INSEE code, ${ }^{13}$ which includes a hundred industrial categories. In the present study job mobility was defined in such a way as to permit the isolation, within the sample, of the group comprising the most mobile subjects. For this purpose we considered both the number of different companies involved in the subject's occupational history and the number of branches of economic activity.

A subject was considered to have been highly mobile when both the number of companies and branches of economic activity were larger than the averages seen for the respondents as a whole.

The mean number of companies for which subjects had worked was $5 \cdot 7$ for men (SD 6.3) and 6.5 for women (SD 7.0). The mean number of branches of economic activity was 2.8 for men (SD 2.2 ) and 3.4 for women (SD 2.3, table 1). As these numbers were similar, we used the same limits to define job mobility for men and women. Subjects with high job mobility

Table 1 Mean age and past occupational characteristics of the men and women respondents and non-respondents

\begin{tabular}{|c|c|c|c|c|c|c|}
\hline & \multicolumn{3}{|l|}{ Men } & \multicolumn{3}{|l|}{ Women } \\
\hline & $\begin{array}{l}\text { Respondents } \\
(n=317)\end{array}$ & $\begin{array}{l}\text { Non-respondents } \\
(n=164)\end{array}$ & p Value & $\begin{array}{l}\text { Respondents } \\
(n=303)\end{array}$ & $\begin{array}{l}\text { Non-respondents } \\
(n=202)\end{array}$ & $p$ Value \\
\hline $\begin{array}{l}\text { Mean age }(y)(S D) \\
\text { Mean No of companies }(S D) \\
\text { Mean No of branches of }\end{array}$ & $\begin{array}{r}68 \cdot 5(3 \cdot 7) \\
5 \cdot 7(6 \cdot 3)\end{array}$ & $\begin{array}{l}69 \cdot 0(2 \cdot 09) \\
6 \cdot 1(5 \cdot 9)\end{array}$ & $\begin{array}{l}\text { NS } \\
\text { NS }\end{array}$ & $\begin{array}{r}68 \cdot 5(3 \cdot 6) \\
6 \cdot 5(7 \cdot 0)\end{array}$ & $\begin{array}{r}68 \cdot 9(3 \cdot 1) \\
5 \cdot 7(5 \cdot 0)\end{array}$ & $\begin{array}{l}\text { NS } \\
\text { NS }\end{array}$ \\
\hline $\begin{array}{l}\text { economic activity (SD) } \\
\text { Subjects with high mobility (\%) }\end{array}$ & $20 \cdot 8(2 \cdot 2)$ & $25 \cdot 6(2 \cdot 0)$ & $\begin{array}{l}\text { NS } \\
\text { NS }\end{array}$ & $\begin{array}{c}3 \cdot 4(2 \cdot 3) \\
27 \cdot 4\end{array}$ & $\begin{aligned} 3 \cdot 4(2 \cdot 1) & \\
22 \cdot 8 & \end{aligned}$ & $\begin{array}{l}\text { NS } \\
\text { NS }\end{array}$ \\
\hline
\end{tabular}


were those who had worked in seven or more different companies and four or more distinct branches of economic activity.

\section{BIAS AND CONFOUNDING FACTORS}

The number of firms and branches of activity on which mobility criteria were based depended on the completeness of the information regarding subjects' employment history collected by the pension fund. In this respect the data concerning the duration of each period of activity did not seem complete for all subjects. We allowed for this bias by adjusting the relation between mobility and the number of impairments to the total known duration of working life (dates of termination of the last job recorded and of the start of the first job recorded) and of the duration of poorly defined periods of working activity for which the firms concerned were not identified.

Confounding factors were selected for their possible effects on the number of impairments. We took account of subjects' socioeconomic category during their longest period of employment (professional, technical and managerial workers, clerical and sales workers, blue collar workers), of their age at the time of the survey $(\leq 66,67-8,69-70$ or $\geq 71)$, of age at retirement ( $<$ or $\geq 63$ ), of episodes in the medical history of the subjects that they considered serious (yes/no), and of any history of accidents during work (yes/no). We also took into account past occupational exposures because of the significant links found between exposure and specific health impairments during a previous study connected with the same survey. ${ }^{9}$ These exposures were identified from subjects' answers to a series of closed ended questions included in the home interview. Two types of exposure were considered, defined as environmental working constraints (dust, noise, heat, toxic products, and bad weather) and physical constraints (carrying of heavy loads, awkward postures, and vibrations). Subjects were considered to have been exposed to these constraints if they stated that they had undergone one of the specific types of exposure mentioned above.

\section{STATISTICAL ANALYSIS}

In the analysis of the results men and women were considered separately. The crude link between job mobility and the number of health impairments was explored by a comparison of means. Initially, the relationship studied was adjusted for confounding factors by two way analysis of variance with quantitative estimation of health state according to the number of impairments. Subsequently, health state was evaluated qualitatively by the variable "two or more impairments," and multiple logistic regression models were used for the adjustments. We chose two or more impairments as the limit because this number was just above the mean for the number of impairments seen in the sample population. In the multivariate analysis, age at the time of the survey was classified into two categories $(<$ or $\geqslant 69)$ to strengthen the power of the analysis.

For three of the 320 men and four of the 307 women who participated the information supplied by the pension fund was not available; hence the statistical analysis only concerned 317 men and 303 women.

\section{Results}

The mean age of the respondents at the time of the survey was 68.5 for both sexes, with a standard deviation (SD) of 3.7 for the men and 3.6 for the women and extreme ages of 61 and 84 . Mean age at retirement was 62.7 for the men (SD 3.6) and 62.9 for the women (SD 3.7) with extremes of 42 and 71 . In the three main socioeconomic categories considered, the percentages of men and women with the longest lasting job in their occupational history were: professional, technical, and managerial workers $37 \%$ of the men and $16 \%$ of the women; clerical and sales workers $10 \%$ of the men and $36 \%$ of the women; and blue collar workers $43 \%$ of the men and $42 \%$ of the women. The proportions for the other socioeconomic categories were $10 \%$ for men and $6 \%$ for women.

The mean numbers of impairments were 1.4 for men (SD 1.1) and 1.8 for women (SD 1.2). Forty two and a half per cent of the men and $55.4 \%$ of the women stated that they had two or more impairments at the time of the survey. According to the mobility criteria chosen for the study $21 \%$ of the men and $27 \%$ of the women were extremely mobile.

Of those selected for the survey $36.9 \%$ were nonrespondents. On the basis of the information supplied by the pension fund we compared respondents and non-respondents for age, number of firms for which they had worked, and number of branches of activity in which they had been employed. The mean ages of non-respondent men and women were 69.0 and 68.9 respectively at the time of selection. The mean number of companies was $6 \cdot 1$ for the men and 5.7 for the women, and the mean number of branches of activity was 3.1 for the men and 3.4 for the women. These numbers were not significantly different from those found among the respondents (table 1).

Subjects with high job mobility had worked for total periods that were significantly longer than those recorded for subjects with low job mobility. On the other hand the duration of the unspecified periods of activity was not different between the two groups. For the men, the percentage of mobile subjects correlated with their socioeconomic category and was larger for clerical and sales workers and blue collar workers than professional, technical, and managerial workers. As regards retirement age, no significant difference 
Table 2 Past occupational characteristics (\%) according to job mobility ${ }^{\star}$ for men and women

\begin{tabular}{|c|c|c|c|c|c|c|}
\hline & \multicolumn{3}{|l|}{ Men } & \multicolumn{3}{|l|}{ Women } \\
\hline & $\begin{array}{l}\text { Mobility } \\
\text { low }\end{array}$ & high & p Value & $\begin{array}{l}\text { Mobility } \\
\text { low }\end{array}$ & high & p Valu \\
\hline $\begin{array}{l}\text { Total duration of known occupational activity: } \\
\quad<40 \text { years } \\
\geq 40 \text { years }\end{array}$ & $\begin{array}{l}50(126) \\
50(126)\end{array}$ & $\begin{array}{l}20(13) \\
80(52)\end{array}$ & $<0.001$ & $\begin{array}{l}57 \cdot 3(126) \\
42 \cdot 7(94)\end{array}$ & $\begin{array}{l}19 \cdot 3(16) \\
80 \cdot 7(67)\end{array}$ & $<0.00$ \\
\hline $\begin{array}{l}\text { Duration of unspecified occupational activity: } \\
<5 \text { years } \\
\geq 5 \text { years }\end{array}$ & $\begin{array}{l}83 \cdot 7(211) \\
16 \cdot 3(41)\end{array}$ & $\begin{array}{l}76 \cdot 9(50) \\
23 \cdot 1(15)\end{array}$ & NS & $\begin{array}{l}70 \cdot 9(156) \\
29 \cdot 1(64)\end{array}$ & $\begin{array}{l}63 \cdot 7(53) \\
36 \cdot 3(30)\end{array}$ & NS \\
\hline $\begin{array}{l}\text { Socioeconomic category: } \\
\text { Professional, technical and managerial workers } \\
\text { Clerical and sales workers } \\
\text { Blue collar workers }\end{array}$ & $\begin{array}{l}88(103) \\
74 \cdot 2(23) \\
73 \cdot 2(101)\end{array}$ & $\begin{array}{l}12(14) \\
25 \cdot 8(8) \\
26 \cdot 8(37)\end{array}$ & $<0.05$ & $\begin{array}{l}77 \cdot 6(38) \\
75(84) \\
68 \cdot 5(89)\end{array}$ & $\begin{array}{l}22 \cdot 4(11) \\
25(28) \\
31 \cdot 5(41)\end{array}$ & NS \\
\hline $\begin{array}{l}\text { Age at retirement: } \\
\quad<63 \\
\quad \geq 63\end{array}$ & $\begin{array}{l}41 \cdot 8(104) \\
58 \cdot 2(145)\end{array}$ & $\begin{array}{l}45 \cdot 3(29) \\
54 \cdot 7(35)\end{array}$ & NS & $\begin{array}{l}40.4(88) \\
59.6(130)\end{array}$ & $\begin{array}{l}43 \cdot 9(36) \\
56 \cdot 1(46)\end{array}$ & NS \\
\hline
\end{tabular}

${ }^{\star}$ See definition in methods section. NS = non-significant. Nos of subjects in parentheses.

was found between the high and low mobility groups (table 2).

Among the men, those in the high mobility group stated that they were suffering from an average of 1.7 impairments, and those in the low mobility group from an average of 1.3 impairments. For the women these numbers were respectively $2 \cdot 1$ and $1 \cdot 7$ (table 3 ). These differences were statistically significant for both sexes.

Exploration of the relation between job mobility

Table 3 Mean number of impairments according to job mobility ${ }^{\star}$ for men and women

\begin{tabular}{lclll}
\hline & Job mobility & \\
\cline { 2 - 4 } & low & high & p Value \\
\hline No of men & 252 & 65 & \\
Mean No of impairments (SD) & $1.3(1.0)$ & $1.7(1.2)$ & $<0.05$ \\
No of women & 220 & 83 & \\
Mean No of impairments (SD) & $1.7(1.2)$ & $2.1(1.0)$ & $<0.05$ \\
\hline
\end{tabular}

«See definition in methods section. and each type of impairment showed that for both sexes the frequency of all the impairments was greater among high than low mobility subjects (table 4). This difference was significant for gastrointestinal and mental health impairments among the men and for musculoskeletal and cardiorespiratory impairments among the women.

When the impairment/mobility relation was adjusted to the known periods of activity ( $>$ or $\leq 40$ years), it was still statistically significant for both men and women. The results were similar after adjustment for the duration of unspecified activity (more or less than five years) in the occupational history recorded by the pension fund (table 5). Among the subjects for whom the duration of known periods of activity exceeded 40 years, the mean number of impairments was larger in the high than the low mobility group (men 1.7 (SD 1.2) v 1.4 (SD 1.1); women 2.0 (SD 1.0) $v 1.5$ (SD 1.1). The degree of significance was 0.08 for the men, and the difference was significant for the women.

For the women separate adjustment for age at the time of the survey, age at retirement, previous diseases, past work accidents, socioeconomic

Table 4 Frequency of impairments (\%) according to job mobility for men and women

\begin{tabular}{|c|c|c|c|c|c|c|}
\hline \multirow[b]{2}{*}{ Impairment } & \multicolumn{3}{|l|}{ Men } & \multicolumn{3}{|l|}{ Women } \\
\hline & $\begin{array}{l}\text { Mobility } \\
\text { low }\end{array}$ & high & p Value & $\begin{array}{l}\text { Mobility } \\
\text { low }\end{array}$ & high & p Value \\
\hline $\begin{array}{l}\text { Musculoskeletal } \\
\text { Cardiorespiratory } \\
\text { Sight or hearing } \\
\text { Gastrointestinal } \\
\text { Mental health }\end{array}$ & $\begin{array}{l}50 \cdot 8(128) \\
34 \cdot 5(87) \\
36 \cdot 9(93) \\
5 \cdot 2(13) \\
4 \cdot 4(11)\end{array}$ & $\begin{array}{l}53.9(35) \\
41.5(27) \\
47.7(31) \\
13.9(9) \\
10.8(7)\end{array}$ & $\begin{array}{l}\text { NS } \\
\text { NS } \\
\text { NS } \\
<0.05 \\
<0.05\end{array}$ & $\begin{array}{l}67 \cdot 3(148) \\
35 \cdot 9(79) \\
36 \cdot 8(81) \\
13 \cdot 6(30) \\
15 \cdot 5(34)\end{array}$ & $\begin{array}{l}80 \cdot 7(67) \\
48 \cdot 2(40) \\
42 \cdot 2(35) \\
19 \cdot 3(16) \\
15 \cdot 7(13)\end{array}$ & $\begin{array}{l}<0.05 \\
0.05 \\
\text { NS } \\
\text { NS } \\
\text { NS }\end{array}$ \\
\hline
\end{tabular}

* See definition in methods section.

Nos of subjects in parentheses. 
Table 5 Mean number of impairments according to job mobility ${ }^{\star}$ and occupational, demographic, health, and work characteristics for men and women

\begin{tabular}{|c|c|c|c|c|c|c|}
\hline \multirow[b]{2}{*}{ Impairment } & \multicolumn{3}{|l|}{ Men } & \multicolumn{3}{|l|}{ Women } \\
\hline & $\begin{array}{l}\text { Mobility } \\
\text { low }\end{array}$ & high & p Value & $\begin{array}{l}\text { Mobility } \\
\text { low }\end{array}$ & high & p Value \\
\hline $\begin{array}{l}\text { Known duration of occupational activity: } \\
<40 \text { years } \\
\geq 40 \text { years }\end{array}$ & $\begin{array}{l}\mathrm{n}=126 \\
1 \cdot 3(1 \cdot 0) \\
\mathrm{n}=126 \\
1 \cdot 4(1 \cdot 1)\end{array}$ & $\begin{array}{l}n=13 \\
1 \cdot 6(1 \cdot 3) \\
n=52 \\
1 \cdot 7(1 \cdot 2)\end{array}$ & $<0.05$ & $\begin{array}{l}\mathrm{n}=126 \\
1 \cdot 8(1 \cdot 3) \\
\mathrm{n}=94 \\
1 \cdot 5(1 \cdot 1)\end{array}$ & $\begin{array}{l}n=16 \\
2 \cdot 4(1 \cdot 2) \\
n=67 \\
2 \cdot 0(1 \cdot 0)\end{array}$ & $<0.01$ \\
\hline $\begin{array}{l}\text { Duration of unspecified occupational activity: } \\
<5 \text { years } \\
\geq 5 \text { years }\end{array}$ & $\begin{array}{l}\mathrm{n}=211 \\
1 \cdot 2(1 \cdot 0) \\
\mathrm{n}=41 \\
1 \cdot 7(1 \cdot 1)\end{array}$ & $\begin{array}{l}\mathrm{n}=50 \\
1 \cdot 7(1 \cdot 2) \\
\mathrm{n}=15 \\
1 \cdot 7(1 \cdot 0)\end{array}$ & $<0.05$ & $\begin{array}{l}\mathrm{n}=156 \\
1 \cdot 7(1 \cdot 3) \\
\mathrm{n}=64 \\
1 \cdot 7(1 \cdot 1)\end{array}$ & $\begin{array}{l}\mathrm{n}=53 \\
2 \cdot 0(1 \cdot 1) \\
\mathrm{n}=30 \\
2 \cdot 2(0 \cdot 9)\end{array}$ & $<0.05$ \\
\hline $\begin{array}{l}\text { Age at the time of the survey: } \\
\leq 66 \\
67-8 \\
69-70 \\
\geq 71\end{array}$ & $\begin{array}{l}\mathrm{n}=63 \\
1 \cdot 4(1 \cdot 2) \\
\mathrm{n}=69 \\
1 \cdot 3(0 \cdot 9) \\
\mathrm{n}=49 \\
1 \cdot 3(1 \cdot 1) \\
\mathrm{n}=71 \\
1 \cdot 2(1 \cdot 0)\end{array}$ & $\begin{array}{l}\mathrm{n}=24 \\
2 \cdot 0(1 \cdot 2) \\
\mathrm{n}=16 \\
1 \cdot 1(1 \cdot 0) \\
\mathrm{n}=9 \\
1 \cdot 8(1 \cdot 3) \\
\mathrm{n}=16 \\
1 \cdot 6(1 \cdot 1)\end{array}$ & $<0.05$ & $\begin{array}{l}\mathrm{n}=64 \\
2 \cdot 0(1 \cdot 2) \\
\mathrm{n}=35 \\
1 \cdot 3(1 \cdot 1) \\
\mathrm{n}=50 \\
1 \cdot 6(1 \cdot 4) \\
\mathrm{n}=71 \\
1 \cdot 6(1 \cdot 1)\end{array}$ & $\begin{array}{l}\mathrm{n}=20 \\
2 \cdot 2(1 \cdot 1) \\
\mathrm{n}=23 \\
2 \cdot 1(1 \cdot 0) \\
\mathrm{n}=17 \\
2 \cdot 2(1 \cdot 1) \\
\mathrm{n}=23 \\
1 \cdot 8(0 \cdot 9)\end{array}$ & $<0.01$ \\
\hline $\begin{array}{l}\text { Age at retirement: } \\
<63 \\
\geq 63\end{array}$ & $\begin{array}{l}\mathrm{n}=104 \\
1 \cdot 5(1 \cdot 1) \\
\mathrm{n}=145 \\
1 \cdot 2(1 \cdot 0)\end{array}$ & $\begin{array}{l}\mathrm{n}=29 \\
2 \cdot 0(1 \cdot 4) \\
\mathrm{n}=35 \\
1 \cdot 4(0 \cdot 9)\end{array}$ & $<0.05$ & $\begin{array}{l}\mathrm{n}=88 \\
1 \cdot 9(1 \cdot 1) \\
\mathrm{n}=130 \\
1 \cdot 5(1 \cdot 1)\end{array}$ & $\begin{array}{l}n=36 \\
2 \cdot 4(1 \cdot 1) \\
n=46 \\
1 \cdot 8(0 \cdot 9)\end{array}$ & $<0.05$ \\
\hline $\begin{array}{l}\text { Previous serious diseases: } \\
\text { No } \\
\text { Yes }\end{array}$ & $\begin{array}{l}\mathrm{n}=123 \\
1 \cdot 1(0 \cdot 9) \\
\mathrm{n}=129 \\
1 \cdot 6(1 \cdot 1)\end{array}$ & $\begin{array}{l}\mathrm{n}=27 \\
1 \cdot 3(1 \cdot 1) \\
\mathrm{n}=38 \\
1 \cdot 9(1 \cdot 2)\end{array}$ & $<0.05$ & $\begin{array}{l}\mathrm{n}=104 \\
1.4(1 \cdot 1) \\
\mathrm{n}=116 \\
1.9(1 \cdot 3)\end{array}$ & $\begin{array}{l}n=35 \\
2 \cdot 1(1 \cdot 0) \\
n=48 \\
2 \cdot 0(1 \cdot 1)\end{array}$ & $<0.05$ \\
\hline $\begin{array}{l}\text { Past work accidents: } \\
\text { No } \\
\text { Yes }\end{array}$ & $\begin{array}{l}\mathrm{n}=179 \\
1 \cdot 1(1 \cdot 0) \\
\mathrm{n}=73 \\
1 \cdot 8(1 \cdot 0)\end{array}$ & $\begin{array}{l}\mathrm{n}=41 \\
1 \cdot 6(1 \cdot 2) \\
\mathrm{n}=24 \\
1 \cdot 8(1 \cdot 1)\end{array}$ & $<0.05$ & $\begin{array}{l}\mathrm{n}=182 \\
1 \cdot 6(1 \cdot 2) \\
\mathrm{n}=38 \\
2 \cdot 2(1 \cdot 3)\end{array}$ & $\begin{array}{l}n=60 \\
2 \cdot 0(1 \cdot 0) \\
n=23 \\
2 \cdot 1(1 \cdot 2)\end{array}$ & $<0.05$ \\
\hline $\begin{array}{l}\text { Socioeconomic category: } \\
\text { Professional, technical, and managerial } \\
\text { workers } \\
\text { Clerical and sales workers } \\
\text { Blue collar workers }\end{array}$ & $\begin{array}{l}\mathrm{n}=103 \\
1 \cdot 2(1 \cdot 0) \\
\mathrm{n}=23 \\
1 \cdot 2(0 \cdot 9) \\
\mathrm{n}=101 \\
1 \cdot 5(1 \cdot 1)\end{array}$ & $\begin{array}{l}\mathrm{n}=14 \\
1 \cdot 1(1 \cdot 0) \\
\mathrm{n}=8 \\
1.9(1 \cdot 6) \\
\mathrm{n}=37 \\
1.9(1 \cdot 1)\end{array}$ & 0.09 & $\begin{array}{l}\mathrm{n}=38 \\
1 \cdot 2(1 \cdot 1) \\
\mathrm{n}=84 \\
1 \cdot 7(1 \cdot 1) \\
\mathrm{n}=89 \\
1 \cdot 9(1 \cdot 4)\end{array}$ & $\begin{array}{l}n=11 \\
1 \cdot 5(0 \cdot 8) \\
n=28 \\
2 \cdot 0(1 \cdot 0) \\
n=41 \\
2 \cdot 2(1 \cdot 1)\end{array}$ & $<0.05$ \\
\hline $\begin{array}{l}\text { Occupational exposures: } \\
\text { Environmental working constraints } \\
\text { No } \\
\text { Yes }\end{array}$ & $\begin{array}{l}\mathrm{n}=130 \\
1 \cdot 2(1 \cdot 0) \\
\mathrm{n}=122 \\
1 \cdot 4(1 \cdot 1)\end{array}$ & $\begin{array}{l}\mathrm{n}=33 \\
1 \cdot 6(1 \cdot 3) \\
\mathrm{n}=32 \\
1 \cdot 8(1 \cdot 1)\end{array}$ & $<0.05$ & $\begin{array}{l}\mathrm{n}=155 \\
1 \cdot 5(1 \cdot 2) \\
\mathrm{n}=65 \\
2 \cdot 1(1 \cdot 1)\end{array}$ & $\begin{array}{l}\mathrm{n}=58 \\
2 \cdot 0(1 \cdot 0) \\
\mathrm{n}=25 \\
2 \cdot 3(1 \cdot 0)\end{array}$ & $<0.05$ \\
\hline $\begin{array}{l}\text { Physical constraints } \\
\text { No } \\
\text { Yes }\end{array}$ & $\begin{array}{l}\mathrm{n}=166 \\
1 \cdot 2(1 \cdot 0) \\
\mathrm{n}=86 \\
1 \cdot 6(1 \cdot 1)\end{array}$ & $\begin{array}{l}\mathrm{n}=40 \\
1 \cdot 5(1 \cdot 2) \\
\mathrm{n}=25 \\
1 \cdot 5(1 \cdot 2)\end{array}$ & $<0.05$ & $\begin{array}{l}\mathrm{n}=162 \\
1 \cdot 6(1 \cdot 2) \\
\mathrm{n}=58 \\
2 \cdot 0(1 \cdot 2)\end{array}$ & $\begin{array}{l}\mathrm{n}=47 \\
2 \cdot 0(1 \cdot 0) \\
\mathrm{n}=36 \\
2 \cdot 2(1 \cdot 0)\end{array}$ & $<0.05$ \\
\hline
\end{tabular}

«See definition in methods section.

$p$ Value related to job mobility obtained from two way analysis of variance.

$\mathrm{n}=$ No of subjects.

SD in parentheses. 
Table 6 Number of impairments (two or more) according to job mobility for men and women: adjusted odds ratio $(O R)$ *

\begin{tabular}{|c|c|c|}
\hline & $\begin{array}{l}\text { Men } \\
\text { OR }(95 \% C I) \dagger\end{array}$ & $\begin{array}{l}\text { Women } \\
\text { OR }(95 \% \text { CI }) \dagger\end{array}$ \\
\hline $\begin{array}{l}\text { Whole sample: } \\
\text { Low mobility } \\
\text { High mobility }\end{array}$ & $\frac{1}{1.57}(0.85-2.81)$ & $\frac{1}{2 \cdot 07}(1 \cdot 16-3 \cdot 68)$ \\
\hline $\begin{array}{c}\text { Clerical and sales } \\
\text { Low mobility } \\
\text { High mobility }\end{array}$ & $\begin{array}{l}\text { ers and blue collar } \\
1 \\
2.04(0.96-4.33)\end{array}$ & $\begin{array}{l}\text { kers: } \\
\frac{1}{2.54}(1.33-4.84)\end{array}$ \\
\hline
\end{tabular}

*Adjusted for age at the time of the interview, age at retirement, previous diseases, past work accidents, socioeconomic category (for whole sample only), environmental constraints, and physical contraints.

$\lceil 95 \% \mathrm{CI}$ for the adjusted odds ratio.

category, and constraints at work did not change the statistical significance of the link between the number of impairments and job mobility. For the men, the results of these adjustment tests were similar to those for the women except for socioeconomic category, for which the degree of significance after adjustment was 0.09 .

The relation between mobility and impairments was then analysed by a multiple logistic regression model in which the variable investigated was "two or more impairments." The model included job mobility, age at the time of the survey, age at retirement, socioeconomic category, medical history, history of accidents at work, and occupational exposure to physical and/or environmental constraints. The adjusted odds ratio for high mobility $v$ low mobility was 1.6 for men and 2.1 for women (table 6), and was only significant for the women. The same model was then applied solely to the clerical and sales workers and blue collar workers whose mobility was greater than that of the professional, technical, and managerial workers. In this model, the socioeconomic category was omitted from the adjustment variables. As a result, the adjusted odds ratio rose by about 2 for the men and 2.5 for the women. This was significantly greater than 1 for the women, and at the limit of significance for the men $(95 \%$ confidence interval (95\% CI) $0.96-4 \cdot 33)$.

\section{Discussion}

In the present study of a retired population living in the Paris area we found a significant relation between job mobility defined as the number of changes of company and branch of activity during working life and the number of health impairments after retirement. Subjects with high mobility had on average a larger number of impairments after retirement than subjects with low mobility.

The interpretation of this finding raises several questions. Firstly, possible bias must be considered. The population from which the sample was drawn was made up of previously selected subjects. In particular, they were subjects who were still alive after a mean retirement period of six years. The differential expectation of life according to sex and social class ${ }^{14} 15$ allowed us to assume that the weakest or most affected subjects had already died before retirement and were therefore automatically excluded from the present sample. Although this exclusion is generally believed to weaken the intensity of the relation seen between occupational factors and health, the relation found here between job mobility and the number of impairments after retirement was statistically significant.

The health of non-respondents is, a priori, likely to be different and probably worse than that of the people who participate in a study. The present sample is still being followed up for mortality. After five years of follow up the cumulative incidence of mortality seemed to be similar between respondents and non-respondents $(20 \%$ of respondents and $21 \%$ of non-respondents among the men and 6 and $7 \%$ respectively among the women). This finding enables us to assume that those who participated in the study had not been selected on the basis of health factors related to mortality.

Also, it was important to consider the possibility that our participants might have been selected for their occupational history. The present results, however, showed that participation in the survey did not seem to be related to the occupational characteristics determining the mobility criteria.

In both sexes, the duration of the working activity recorded by the pension fund was longer in the high than the low mobility group. This, therefore, raised the question of whether this difference did not explain the mobility/impairment relation seen. When the last was adjusted for the duration of working activity, however (more or less than 40 years), it remained statistically significant. Therefore, it was reasonable to assume that even if a bias connected with the duration of working activity existed, it did not explain the relation found.

Confounding factors taken into account were age at the time of the survey, age at retirement, socioeconomic category of each subject during the job that lasted longest, medical history of disease, past work accidents, and occcupational exposures. None of them seemed to alter the mobility/impairment relation. Particularly, in the multivariate analysis, this relation remained significant for the women. For the men, limitation of the analysis to clerical and sales workers and blue collar workers resulted in an adjusted odds ratio of $2 \cdot 0$, which was close to statistical significance. Omission of the professional, technical, and managerial workers weakened the dilution effect stemming from the small percentage of mobile subjects in the management group.

Social mobility, as Kaplan et al ${ }^{16}$ argued could be a 
confounding factor. In our study one parameter of social mobility was measured-namely, the changes in socioeconomic category that occurred between the end of the longest period of employment in the same job and the beginning of the last job before retirement. This social mobility concerned $11 \%$ of the men and $20 \%$ of the women. For both sexes the mean number of impairments was larger among those who changed their socioeconomic category. The statistical significance of the mobility/impairment relation remained, however, after adjustment for social mobility. In this study, it was not possible to take into account the direction of the changes in socioeconomic category because in our sample there were few important social changes such as that of worker to executive.

Therefore, although an artefact effect could not be completely excluded on account of other possible confounding factors our results suggest, on the whole, that greater job mobility during working life might be linked to a worse state of health after retirement. This conclusion seems independent of sex even though the values for several occupational or non-occupational parameters were different for men and women.

How, then, should the mobility/impairment relation be interpreted? The above conclusion might reflect the traditional selection of workers on the basis of health, which means that poor health would lead to change of job, with the subject searching for a job better adjusted to his or her health condition. Examples of such selection are given by Fox and Collier's survey ${ }^{4}$ of the mortality of subjects employed in the polyvinyl chloride industry between 1940 and 1974 in Great Britain. Among the subjects who were still alive 15 years after entering this industry, those still working in the industry had a lower mortality $(S M R=74)$, and those who had left it had a higher mortality (SMR $=108.4$ ) than the general population. Similarly, Ostlin found that the prevalence of morbidity was higher among subjects who had left jobs with severe physical constraints for jobs with less severe constraints, than among subjects who had always worked in the less severe constraint type of job (relative risk 1.43 for the men and 1.53 for the women).

Negative selection for jobs by health state throughout working life certainly also existed in our sample and for this reason the mobility found here may partly reflect job changes due to health. Nevertheless, we wonder whether this suffices to explain the relation we found between mobility and the number of impairments. Many reasons exist for changing jobs, which are not primarily connected with health, including the desire for a higher income, better working conditions, and a job more fitted to the applicant's qualifications. A type of mobility is also induced by fluctuations in the employment market due to the setting up and closing down of companies. At the same time all these changes may affect health because of the effort required to adapt to new working environments, changes in the way of life, or the cumulative effects of the occupational exposure experienced in different jobs. It seems reasonable, therefore, not to rule out the possibility that high job mobility might have its own particular effect on health.

High job mobility has been found to be related to cardiovascular diseases. In a study conducted in North Dakota with 203 patients and 406 controls, all of whom were white men aged 35 or more, Syme and Coll ${ }^{6}$ noted that the proportion of subjects who had worked in four or more jobs was higher among the patients. In another study in California covering 80 patients with coronary heart disease and 80 controls, all white men aged from 45 to 64, Syme and $\mathrm{Coll}^{7}$ again found higher mobility (three or more jobs) among the patients. Kaplan and coworkers ${ }^{16}$ also reported that coronary heart disease was more frequent among subjects who had improved their social position after changes of job.

Further investigations are required to examine this question thoroughly, especially prospective surveys yielding more precise information about job changes and the evolution of health. Similarly, the relation between mobility and health should be examined in subjects belonging to generations other than the one considered in the present survey, in which the subjects were born between 1915 and 1922 .

In conclusion, if the mobility/impairment relation we found here was confirmed, it would suggest that health conditions after retirement should be considered, not only in relation to specific occupational exposure or sociological characteristics such as socioeconomic category, but also in relation to factors associated with the pattern of working life before retirement, one of which is job mobility.

The study was supported by INSERM (Institut National de la Santé et de la Recherche Médicale), GRASP (Groupe de Recherches Appliquées à la Santé post-professionnelle), CNAM (Caisse Nationale d'Assurances Maladie), and IPSIE (Institut de Prévoyance Sociale Inter-Entreprise).

1 Laulhe $\mathrm{P}$, Soleilhavoup J. Mobilité professionnelle, enquête FQP 1985. Les collections de l'INSEE D 121, Paris: Imprimerie Nationale, 1987.

2 Monson RR. Observations on the Healthy Worker Effect. $J$ Occup Med 1986;28:425-33.

3 Vinni K, Hakama M. Healthy worker effect in the total Finnish population. Br J Ind Med 1980;37:180-4.

4 Fox AJ, Collier PF. Low mortality rates in industrial cohort studies due to selection for work and survival in the industry. British Journal of Preventative and Social Medicine 1976;30:225-30.

5 Ostlin P. Negative health selection into physically light occupations. J Epidemiol Community Health 1988;42:152-6.

6 Syme SL, Hyman MM, Enterline PE. Some social and cultural 
factors associated with the occurrence of coronary heart disease. J Chronic Dis 1964;17:277-89.

7 Syme SL, Borhani NO, Buechlet RW. Cultural mobility and coronary heart disease in an urban area. Am J Epidemiol 1966;82:334-46.

8 Collins JF, Redmond CK. The use of retirees to evaluate occupational hazards. J Occup Med 1976;18:595-602.

9 Derriennic F, Cassou B, Lecuyer G, Amphoux M. Déficiences locomotrice et cardiorespiratoire après la retraite en relation avec certaines expositions professionnelles durant la vie active. Rev Epidemiol Sante Publique 1987;35:263-73.

10 World Health Organization. International classification of impairments, disabilities and handicaps. Geneva: WHO, 1980.

11 Langner TS. A twenty two item screening score of psychiatric symptoms indicating impairment. Journal of Health and Human Behaviour 1962;3:219-76.
12 Ouslander JG, Beck JC. Defining the health problems of the elderly. Ann Rev Public Health 1982;3:55-83.

13 Ministère des Finances et des Affaires Economiques. Nomenclature des activités économiques. Paris: Imprimerie Nationale, 1959.

14 Desplanques G. L'inégalité sociale devant la mort. Economie et Statisque 1984;162:29-50.

15 Markides KS, Machalek R. Selective survival, aging and society. Arch Gerontol Geriat 1984;3:207-22.

16 Kaplan BH, Cassel JC, Tyroler HA, Cornoni JC, Kleinbaum BG, Hames CG. Occupational mobility and coronary heart disease. Arch Intern Med 1971;128:938-42.

Accepted 25 March 1991

\section{Vancouver style}

All manuscripts submitted to the $B r J$ Ind Med should conform to the uniform requirements for manuscripts submitted to biomedical journals (known as the Vancouver style).

The $\mathrm{Br} J$ Ind Med, together with many other international biomedical journals, has agreed to accept articles prepared in accordance with the Vancouver style. The style (described in full in $\mathrm{Br}$ Med J, 24 February 1979, p 532) is intended to standardise requirements for authors.

References should be numbered consecutively in the order in which they are first mentioned in the text by Arabic numerals above the line on each occasion the reference is cited (Manson ${ }^{1}$ confirmed other reports ${ }^{2-5} \ldots$..). In future references to papers submitted to the $\mathrm{Br} J$ Ind Med should include: the names of all authors if there are six or less or, if there are more, the first three followed by et al; the title of journal articles or book chapters; the titles of journals abbreviated according to the style of Index Medicus; and the first and final page numbers of the article or chapter.

Examples of common forms of references are:

1 International Steering Committee of Medical Editors. Uniform requirements for manuscripts submitted to biomedical journals. Br Med J 1979;1:532-5.

2 Soter NA, Wasserman SI, Austen KF. Cold urticaria: release into the circulation of histamine and eosino-phil chemotactic factor of anaphylaxis during cold challenge. N Engl J Med 1976;294:687-90.

3 Weinstein L, Swartz MN. Pathogenic properties of invading micro-organisms. In: Sodeman WA Jr, Sodeman WA eds. Pathologic physiology: mechanisms of disease. Philadelphia: W B Saunders, 1974:457-72. 